УДК 351.83/.84:304

Основні міжнародні тенАенції реформування соліАарної пенсійної системи

\title{
M.B. KPABYEHKO
}

Національна акалемія державного управління при Презилентові України, м. Київ, Україна, E-mail: milenaua@ukr.net

\section{Авторське резюме}

Діагностика державної політики у сфері пенсійного забезпечення показує, що вона характеризується безсистемністю та фрагментарністю здійснюваних заходів, залежністю від політичної ситуації, у тому числі виборчих компаній, обмеженістю інструментарію проведення кардинальних змін, неврахуванням об'єктивних чинників проведення пенсійної реформи тощо. Водночас світова практика має значний доробок заходів і механізмів, які дозволяють покращити стан солідарної пенсійної системи та диверсифікувати джерела отримання пенсій. У статті здійснено аналіз основних міжнародних тенденцій реформування солідарної пенсійної системи, які бажано врахувати в Україні для забезпечення управління у сфері пенсійного забезпечення в умовах обмеження ресурсів і значної диференціації пенсій. Найбільш поширеними тенденціями є: підвищення віку виходу на пенсію для працездатних громадян, стимулювання населення до участі у приватних системах пенсійного забезпечення, сплата пенсійних внесків між роботодавцями і працівниками на паритетних засадах.

Ключові слова: солідарна пенсійна система, міжнародні тенденції реформування пенсійної системи.

\section{Main internationaltrends of reforming the solidary pension system}

\author{
M.V. KRAVCHENKO \\ National academy for public administration under the President of Ukraine, \\ Kyiv, Ukraine, E-mail: milenaua@ukr.net
}

\begin{abstract}
Diagnosis of the state policy on pensionprovision shows that it is characterized by (C) М.В. Кравченко, 2015
\end{abstract}


fragmented and non-systematic ongoing activities, dependence on the political situation, including election campaigns, limited tools of fundamental changes, neglect of the objective pension reform factors, etc. Meanwhile, world practice has a proven track record of measures and mechanisms that allow to improve the state pension system and diversify the sources of pension. The article analyzes the main internationaltrends of solidary pension system reform which could be considered by Ukraine for pension administration in terms of resource constraints and significant differentiation of pensions. The most common trends are: raise of the retirement age for able-bodied citizens, encouragement of people's participation in the private pension system, pension contributions between employers and workers on a parity basis.

Key words: solidary pension system, international trends in pension reform.

Постановка проблеми. Створення державної системи пенсійного забезпечення шляхом солідарного перерозподілу доходів між різними поколіннями населення розпочалося ще в 1889 році Канцлером Німеччини Отто Бісмарком. Пізніше аналогічні пенсійні системи були введені іншими провідними країнами Європи: Данією (1891), Великобританією (1908), Францією (1910), Швецією (1913), Італією (1919). Наслідуючи позитивний приклад європейських країн, у першій половині XX століття решта держав розробили національні солідарні пенсійні системи.

За майже століття функціонування солідарної системи пенсійного забезпечення були створені достатньо надійні механізми гарантій мінімальних доходів пенсіонерам i загалом досить високих трудових пенсій. Попри значні соціальні гарантії та стабільність, остання чверть $\mathrm{XX}$ ст. ознаменувалася світовою кризою пенсійної системи. У 1980-90-ті роки розпочалося реформування пенсійних систем багатьох країн світу: Чилі (1981), Італія та Німеччина (1992), Франція (1993), Велика Британія (1994), США (1995), Латвія (1996), Угорщина (1997), Хорватія (1998), Польща (1999). У цілому криза солідарної пенсійної системи детермінована такими об'єктивними процесами, як старіння населення та уповільнення темпів економічного зростання. Демографічна ситуація значною мірою впливає на суспільний розвиток багатьох держав світу, що змінити практично неможливо [2, с.21]. За прогнозами ООН старіння населення буде залишатися глобальною тенденцією демографічного розвитку протягом XXI століття і до 2100 року майже втричі збільшиться кількість людей пенсійного віку. Поглиблення процесу старіння населення, тобто збільшення питомої ваги людей передпенсійного і пенсійного віку, загострює проблеми фінансування пенсійної системи: зменшується частина платників внесків до пенсійного фонду та збільшується кількість отримувачів пенсій, відповідно, погіршується диспропорція між пенсіонерами і працюючими, підвищуючи фінансове навантаження на останніх. Напругу між поколіннями поглиблюе не тільки зниження народжуваності та смертності, а й збільшення тривалості життя населення, що характерно для високорозвинутих країн. Названі демографічні зміни відображають глибинні соціально-економічні зрушення, які відбувалися протягом століття. Нині стали актуальними такі питання, як викривлення структури соціальних трансфертів, загострення проблем забезпечення потреб населення в медичних, соціальних та інших послугах, зростання пенсійних видатків по відношенню до ВВП.

Уповільнення темпів економічного зростання, яке в розвинутих країнах спостерігається 3 середини $70-\mathrm{x}$ років $\mathrm{XX}$ ст., призводить до обмеження ресурсів на соціальні цілі, ускладнюючи систему накопичення, розподілу та перерозподілу коштів пенсійного забезпечення і послаблюючи зв'язок між трудовим внеском та нарахованою пенсією; зменшується частка платників пенсійних внесків також через високий рівень безробіття і міграції робочої сили у багатьох країнах і через зміну форм зайнятості (поширення неформальної та част- 
кової зайнятості, робота вдома тощо).

Отже, у сучасних умовах солідарна пенсійна система самостійно вже не може адекватно протистояти існуючим демографічним і соціально-економічним викликам. Пошук шляхів розв'язання проблем пенсійного забезпечення призвів до створення нових моделей пенсійної системи.

Аналіз досліджень і публікацій. Злободенна проблематика шляхів реформування солідарної пенсійної системи активно дискутується у науковій літературі [1-11]. Для України пенсійна реформа набула особливої актуальності в умовах дефіциту пенсійного фонду та зростання соціальних видатків, значного розриву між «загальними» $\mathrm{i}$ «спеціальними» пенсіями, виплати зарплат у «конвертах», неадекватної системи оподаткування тощо. Діагностика державної політики у сфері пенсійного забезпечення показує, що вона характеризується безсистемністю та фрагментарністю здійснюваних заходів, залежністю від політичної ситуації, у тому числі виборчих компаній, обмеженістю інструментарію проведення кардинальних змін, неврахуванням об'єктивних чинників проведення реформи тощо. Водночас в інших країнах є значний доробок заходів і механізмів, які дозволяють покращити стан пенсійної системи та диверсифікувати джерела отримання пенсій.

Мета дослідження - здійснити аналіз основних міжнародних тенденцій реформування солідарної пенсійної системи, які бажано врахувати для забезпечення управління у сфері пенсійного забезпечення в умовах обмеження ресурсів i значної диференціації пенсій.

Виклад основного матеріалу. Аналіз зарубіжного досвіду показує, що в сучасних складних фінансово-економічних i демографічних умовах ідеальної системи пенсійного забезпечення фактично не існує. В цілому всі реформаторські заходи зводяться до зміни пенсійних прав громадян i зниження навантаження на бюджет, а також до спроб трансформаціі суспільної психології щодо необхідності узгодження інтересів різних поколінь i забезпечення соціальної справедливості.

Найбільш вдалою для досягнення успіху реформування солідарної пенсійної системи та забезпечення найвищого рівня соціального захисту пенсіонерів у нинішніх умовах вважається нова модель пенсійної системи - змішана трирівнева система, в якій відбувається фінансування пенсій 3 різних джерел. Трирівнева система пенсійного забезпечення нині є найбільш життєздатною, що підтверджують останні дослідження Міжнародної організації праці [8]. Вона охоплює традиційну розподільчу систему, побудовану на принципі солідарності поколінь у більш удосконаленому вигляді, а також містить принципово новий компонент - обов'язкову накопичувальну пенсійну систему та добровільну систему особистих пенсійних збережень. Тобто, у міжнародній практиці загалом, водночас із різними особливостями, застосовується багаторівнева пенсійна система, яка має три складові: солідарну (перший рівень), обов'язкову накопичувальну (другий рівень), додаткову або добровільну накопичувальну (третій рівень).

Зміст реформування солідарної системи полягає у забезпеченні базових принципів соціальної рівності, однакового для всіх захисту від бідності в похилому віці, а також у перегляді підходів до пільг і привілеїв у пенсійному забезпеченні. Держава бере на себе зобов'язання, що всі громадяни будуть мати пенсію, не нижчу прожиткового мінімуму.

Основною метою запровадження накопичувальної пенсійної системи є підвищення розміру пенсій за рахунок доходу, отриманого від інвестування пенсійних внесків громадян у цінні папери, купівля-продаж яких здійснюється на фондовому ринку. Головним принципом накопичувальної системи $\mathrm{\epsilon}$ особиста відповідальність кожної застрахованої особи за формування умов власного життя. Вона спонукає громадян до накопичення власних пенсійних заощаджень на індивідуальному пенсійному рахунку, який $є$ приватною власністю застрахованої особи. Накопичувальна 
система також сприяє збільшенню сукупних національних нагромаджень, внутрішніх довгострокових інвестицій в економіку, сприяе економічному зростанню та підвищенню добробуту громадян. Дохідність накопичувальної системи значно залежить від змін економічної кон'юнктури та якості менеджменту. Переваги багаторівневого пенсійного забезпечення полягають у тому, що існуючі ризики розподіляються між

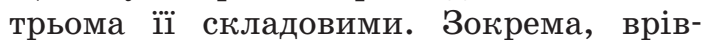
новажуються ризики, пов'язані зі змінами в демографічній ситуації (до чого більше чутлива солідарна система), та 3 коливаннями в економіці і на ринку капіталів (що більше відчувається в накопичувальній системі). Солідарний компонент встановлює зв'язок між пенсією i заробітною платою, а накопичувальний компонент забезпечує можливість для громадян диференціювати розміри пенсії залежно від заробітної плати й ефективності використання пенсійних накопичень, тобто отримати пенсію, розмір якої може перевищувати очікуваний за рахунок вдалого інвестування пенсійних внесків. Солідарна складова враховує інтереси малозабезпечених верств населення, а накопичувальна - стимулює до пенсійних заощаджень усіх громадян, особливо з більш високими доходами. Такий розподіл ризиків дає можливість зробити пенсійну систему більш фінансово збалансованою та стійкою, що застрахує працівників від зниження загального рівня доходів після виходу на пенсію.

Економісти вважають, що поєднання солідарних пенсійних систем першого рівня та накопичувальних пенсійних систем другого та третього рівнів значно підвищує соціальний захист громадян у старості [7]. При цьому держава має вживати заходи для охоплення всіма трьома рівнями пенсійної системи максимальної кількості працездатного населення, інакше система не буде ефективно працювати і виконувати свої функції. Таким чином, у переважної більшості високорозвинутих країн концептуально застосовується трирівнева система пенсійного забезпечення, хоча кожна національна пенсійна система має свої особливості та характерні ознаки, зумовлені демографічними, соціально-економічними, політичними факторами.

3 нашої точки зору основними міжнародними тенденціями змін у сфері пенсійного забезпечення є підвищення віку виходу на пенсію для працездатних громадян, стимулювання громадян до участі у приватних пенсійних системах та сплата пенсійних внесків роботодавцем і працівником на паритетних засадах.

Як зазначалося вище, швидке старіння населення створює фінансове навантаження на державні пенсійні системи, тому багато країн продовжили період працездатності громадян за рахунок підвищення віку виходу на пенсію. За даними ОЕСР, підвищення пенсійного віку на 1 рік скорочує пенсійні витрати на 5-10 \%, тому держави для скорочення чисельності пенсіонерів законодавчо підвищили пенсійний вік, розтягнувши це підвищення на десятиліття [1].

Загалом вік виходу на пенсію збільшено на 5-10 років, тобто 65 років для чоловіків і 60 років для жінок. У деяких країнах пенсійний вік став однаковим для чоловіків і жінок: Канада, Естонія, Латвія, Нідерланди - 65 років; США, Німеччина, Франція та Іспанія - 67 років; Нідерланди і Данія планують збільшити пенсійний вік з 65 до 67 років до 2020-2030 років для обох статей; Великобританія планує збільшити пенсійний вік до 68 років. В Ізраїлі вік виходу на пенсію підвищиться до 70 років для чоловіків і 66 років для жінок [9]. Відтермінування виходу на пенсію для громадян стимулюється підвищенням розміру пенсії (коефіцієнт підвищення становить 0,5-7,5 \% за додатковий рік), період відтермінування 1-5 років.

Окремі країни відмовилися від чіткого пенсійного віку, наприклад Швеція. Починаючи з 61 до 67 років, жителі можуть претендувати на пенсійні виплати зі своїх персональних рахунків (так звану умовно-накопичувальну пенсію, що формується з 2,5 \% відрахувань). Отримати повноцінну пенсію 3 солідарної 
пенсійної системи вони мають право з 67 років. Держава заохочує пізніший вихід на пенсію, підвищуючи їі приблизно на $10 \%$ за кожен рік, що людина пропрацювала після 65 років [10].

Багато країн створили стимулюючі заходи для участі у приватних системах пенсійного забезпечення громадянам працездатного віку.

У Чилі, першій країні, де була запроваджена недержавна система пенсійного забезпечення (з 1981 року), активи пенсійних фондів стали одним із стабільних джерел накопичення, сприяли розвитку житлового будівництва та страхування, реалізації низки високовартісних проектів у сфері інфраструктури. Перші 10 років існувало обмеження вкладення пенсійних коштів в іноземні цінні папери, що дозволило акумулювати в недержавних пенсійних фондах більше $50 \%$ ВВП. Значна кількість утворених недержавних пенсійних фондів (25) створювала передумови для конкуренціі між ними за клієнтів, тим самим сприяючи підвищенню якості i прозорості надання послуг. Крім того, було надано державні гарантії мінімальної пенсії у разі банкрутства недержавних пенсійних фондів та різні форми компенсаціі працівникам для пом'якшення труднощів переходу на накопичувальну систему і стимулювання приєднання до неї тощо. У Швеції працівник має можливість вибрати приватний пенсійний фонд чи навіть кілька фондів з 800 пенсійних фондів, де він розміщуе свої накопичення 3 мінімальною прибутковістю в $3 \%$ річних. Інвестиції пенсійних фондів жорстко регулюються, зокрема діють обмеження на інвестиції в нерухомість або прямі позики. За пенсійними фондами здійснює нагляд міністерство фінансів країни, що проводить щорічну фінансову перевірку та звітує про роботу фондів перед парламентом.

У Нідерландах $90 \%$ працівників залучені в галузеві пенсійні фонди, пенсійні фонди компаній i фонди для самозайнятих. Накопичувальна ставка більшості програм коливається від $1,75 \%$ до $2,2 \%$ річних, що при стажі в 40 років дозволяе компенсувати
70 \% зарплати. Розмір внесків (зазвичай 15-16 \% зарплати) закріплюється в колективному договорі та розподіляється між працівниками і роботодавцем. У Бельгії в 1999 році скасовано вимогу обов'язкового інвестування $15 \%$ активів у державні цінні папери, дозволено для депозитарних послуг залучати організації, у т.ч. банки будь-якої країни СС. Нині Бельгія має одну з найвищих прибутковість пенсійних активів.

У Чехії за останні десять років чисельність учасників приватних пенсійних фондів збільшилася в 15 разів: нині у них бере участь $50 \%$ економічно активного населення. Суттєво підвищує довіру громадян до недержавних пенсійних фондів те, що більшість приватних пенсійних фондів у країні належить іноземним фінансовим структурам зі Швейцарії, Нідерландів, Італії, Бельгії. Іспанія також дозволила пенсійним фондам до $20 \%$ активів передавати для управління іноземним компаніям.

Таким чином, виграють усі суб'єкти цього процесу - приватному сектору фінансово вигідно відкладати гроші для недержавного пенсійного забезпечення своїх працівників, адже ці кошти не надходять державі, а залишаються у приватному секторі, і це досить великий обсяг, а також зростають пенсійні виплати у найманих працівників.

Значна частина країн вдається до перегляду співвідношення щодо сплати пенсійних внесків між роботодавцем i працівником на користь паритетних засад [7]. Фінансування першого рівня трирівневої пенсійної системи у Великій Британії, Люксембурзі та Кіпрі здійснюється роботодавцями і працівниками порівну. У Німеччині працівник і роботодавець відраховують до державного пенсійного фонду однаковий відсоток, що становить 19,4 \% фонду оплати праці. У Швеції також обов'язковий внесок у розмірі 18,5 \% від зарплати порівну ділять між собою роботодавець і найманий працівник, але він частково йде до солідарної системи пенсійного забезпечення (16\%) та на індивідуальний накопичувальний рахунок $(2,5$ \% ). У Польщі роботодавець і найманий працівник від- 
раховують до пенсійної системи в рівній пропорції 19,5 \% заробітної плати, з яких $12 \%$ внеску надходить у систему соціального страхування, а 7,5 \% працівник переводить на накопичувальний рахунок. Також щорічно формується демографічний резерв на випадок значних демографічних коливань (1 \% від суми внесків). У США пенсійна ставка становить $10,7 \%$, яку в рівних частинах сплачують роботодавець і працівник.

У Франції розміри внесків для працівників і роботодавців поступово будуть збільшуватись у період до 2017 року (у 2014 році - на 0,15\%). Раніше ставки внесків становили 6,75 \% для працівників та 8,4 \% для роботодавців. Водночас в Італії внески роботодавців у 2,5 раза перевищують відрахування працівників, в Іспанії внески роботодавців у 5 разів перевищують відрахування працівників. У США, Німеччині, Японії та Італії спроба збільшення доходів пенсійної системи за рахунок підвищення внесків викликало активну протидію учасників. Результатом стала модернізація бази стягнення внесків - у Бельгії, Італії, Швейцарії та Португалії був скасований максимальний рівень заробітної плати при обчисленні страхових внесків.

Висновки. Основними міжнародними тенденціями змін у сфері пенсійного забезпечення $\epsilon$ підвищення віку виходу на пенсію, стимулювання громадян до участі у приватних пенсійних системах та сплата пенсійних внесків роботодавцем і працівником на паритетних засадах, які у цілому покращили ситуацію у солідарній пенсійній системі багатьох країн та дали поштовх для розвитку альтернативної моделі системи пенсійного забезпечення - накопичувальній. Для України впровадження зазначених тенденцій з певних причин виявилося неефективним.

Про «демографічну яму» вітчизняні демографи говорять вже 15-20 років (ще в 1998 році був окремий Указ Президента України «Про основні напрями реформування пенсійного забезпечення в Україні»), але реальних управлінських рішень не було прийнято до 2010 року, коли жінок поставили перед фактом «сьогоднішнього» підвищення пенсійного віку. Підвищення пенсійного віку об'єктивно обумовлено, адже вітчизняна демографічна структура несприятлива - дисбаланс між кількісним співвідношенням поколінь економічно активних і непрацездатних громадян через високий рівень смертності економічно активного населення, особливо чоловіків, та низькі репродуктивні установки, що не дозволить у належній кількості поповнити працюючу частину населення, тобто попереду лише зменшення чисельності населення, насамперед працездатного та допрацездатного віку.

В інших країнах демографічні тенденції враховують у стратегічному плануванні державної політики, що дозволяє здійснити превентивні заходи, зокрема пролонгувати підвищення віку виходу на пенсію, розтягнувши цей процес на 20 років. А в Україні для значного ефекту пенсійний вік у 2010 році треба було підвищувати не на півроку впродовж кожного року, а відразу на п'ять років, зазначає головний вітчизняний демограф Е.М.Лібанова, але з таким підходом дуже жорсткою була б реакція ринку праці - різке збільшення пропозиції робочої сили супроводжувалося б таким самим різким зростанням безробіття. Таким чином, виграш був би досить сумнівним [3]. «Пожежні» заходи в державній політиці не дають очікуваного ефекту.

Стимулювання громадян до участі у приватних пенсійних системах у сучасних фінансово-економічних та суспільно-політичних умовах видається досить проблематичним. Міністерство соціальної політики України анонсувало запровадження обов'язкової накопичувальної системи з 2017 року. Крім очевидних і закріплених законодавчо передумов, ї̈ запровадження (зростання ВВП два роки поспіль має складати не менше $2 \%$, бездефіцитність Пенсійного фонду, звільнення солідарної системи від невластивих їй видатків, створення стимулів роботодавцям для виходу 3 «тіні», підвищення обсягів надходжень у результаті детінізації зайнятості, формування резерву коштів для покриття дефіциту 
у майбутніх періодах тощо) варто здійснити необхідні фінансово-економічні розрахунки реального рівня приватних накопичень 3 урахуванням існуючих ризиків, а також важливим залишається організаційно-технічна готовність функціонування накопичувальної системи та підвищення фінансової грамотності населення, інакше може відбутися дискредитація пенсійної реформи вже на

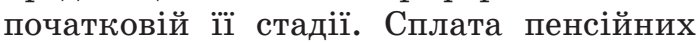
внесків роботодавцем і працівником на паритетних засадах в ідеалі гармонізуе соціально-трудові відносини i сприяє пенсійним заощадженням. В Україні цей захід має відбуватися за відчутного зростання заробітної плати, в тому числі виходу ї̈ 3 «тіні», створення сучасних робочих місць та введення адекватної прогресивної шкали оподаткування. Зазначені заходи створять міцне підгрунт- тя для стимулювання громадян до участі у приватних пенсійних системах. Водночас поточна ситуація характеризується зменшенням частини населення із середніми доходами, що провокує скорочення бази оподаткування та знижує рівень соціальної солідарності, а відсутність прогресивної шкали оподаткування доходів фізичних осіб призводить до перенесення основного фіскального тягаря на значну частину населення, яка отримує невеликі доходи.

Перспективи подальших досліджень вбачаються у прогнозній оцінці ефективності та результативності здійснення вітчизняної пенсійної реформи на основі міжнародного досвіду. Для того, щоб зрозуміти причини адекватного рівню життя пенсійного забезпечення інших країн, потрібно вивчати стратегію і тактику тих, хто цей розвиток створював.

\section{СПИСОК АІТЕРАТУРИ:}

1. Котликофф Л., Бернс С. Пенсионная реформа перед бурей / Л. Котликофф, С. Бернс. Альпина паблишер, 2005. - 348 с.

2. Либанова Э. Демографические сдвиги в контексте социального развития / Э. Либанова // Демографія і соціальна економіка. - 2014. - № 1 (21). - С. 9-22.

3. Либанова Э. Нужно стимулировать экономию - Режим доступу: http:/gazeta.zn.ua/ socium/ella-libanova-nuzhno-stimulirovat-ekonomiyu.html - Назва з екрана.

4. Мірошниченко I. Сучасні проблеми пенсійного забезпечення: зарубіжний досвід та вітчизняні реалії / І. Мірошниченко // Облік і фінанси. - 2012. - № 4 (58). - С. 65-72.

5. Новиков А. Особенности эволюции зарубежных пенсионных систем / А. Новиков // Мировая экономика и международные отношения. - 2006. - № 5. - С. 65-72.

6. Порівняння пенсійних систем у деяких країнах світу. Експертна записка - Режим доступу: http://brc.undp.org.ua - Назва з екрана.

7. Пенсионные системы в период кризиса: Региональный доклад по странам Европы и Центральной Азии / Всемирный банк, 2009. - 26 с.

8. Employment and social protection in the new demographic context [Text]. Report IV. Fourth item on the agenda of International Labour Conference, 102nd Session, 2013. - Geneva, International Labour Office, 2013. - 120 pp.

9. Holzmann R. Adequacy of Retirement Income after Pension Reforms in Central, Eastern, and Southern Europe [Text] / R. Holzman, U. Guven // The International Bank for Reconstruction and Development / The World Bank. 2009. - 81 р. / [Электронный ресурс] // Режим доступу : http://siteresources.worldbank.org

10. Schludi M. The Reform of Bismarckian Pension Systems: A Comparison of Pension Politics in Austria, France, Germany, Italy and Sweden, Amsterdam [Text] / M. Schludi. - Amsterdam University Press, 2005.

11. Whitehouse E. Retirement-income systems in 53 countries - pensions panorama [Text] / E. Whitehous. - Washington: The World Bank, 2007. - 254 p.

\section{REFERENCES:}

1. Kotlikoff L, Berns S. Pensionnaya reforma pered burej (Pension reform before a storm) Alpina pablicher, 2005. - P. 348.

2. Libanova E. Demograficheskie sdvigi v kontekste socialnogo razvitia (Demographic changes 
are in the context of social development), Demografia i socialna ekonomika, 2014. no. 1 (21), pp. 9-22.

3. Libanova E. Nugno stimulirovat ekonomiu (It is needed to stimulate an economy) - Regime to access: http://gazeta.zn.ua/socium/ella-libanova-nuzhno-stimulirovat-ekonomiyu.html

4. Mirochnichenko I. Sychasni problemy pensiynogo zabezpechennia: zarubignyj dosvid ta vitchzniani realii (Modern problems of the pension providing: foreign experience and domestic realities), Oblik i finansy, 2012. no. 4 (58), pp. 65-72.

5. Novikov A. Osobennosti evolucii zarubignuch pensijnyx system (Features of evolution of the foreign pension systems), Mirovaia ekonomika i megdynarodnue otnochenia, 2006. no. 5, pp. 65-72.

6. Porivniania pensijnych system u deyakich krainach svity. Ekspertna zapyska (Comparison of the pension systems is in some countries of the world. Expert message) - Regime to access: http://brc.undp.org.ua

7. Pensionnue sistemy v period krizisa: Regionalnyj doklad po stranam Evropy i Centralnoj Azii (Pension systems in the period of crisis: Regional lecture on the countries of Europe and Central Asia) / Vsemirnyj bank, 2009. - P. 26.

8. Employment and social protection in the new demographic context. Report IV. Fourth item on the agenda of International Labour Conference, 102nd Session, 2013. - Geneva, International Labour Office, 2013. pp.120

9. Holzmann R. Adequacy of Retirement Income after Pension Reforms in Central, Eastern, and Southern Europe/ Regime to access: http://siteresources.worldbank.org

10. Schludi M. The Reform of Bismarckian Pension Systems: A Comparison of Pension Politics in Austria, France, Germany, Italy and Sweden, Amsterdam - Amsterdam University Press, 2005.

11. Whitehouse E. Retirement-income systems in 53 countries - pensions panorama - Washington: The World Bank, 2007. p. 254

Кравченко Мілена В’ячеславівна - доктор наук з державного управління, професор Національна академія державного управління при Президентові України Адреса: 03057, м. Київ, вул. Ежена Потьє, 20

E-mail: general@academy.gov.ua

Kravchenko Milena Viacheslavivna - doctor of public administration, Full Prof.

National academy for public administration under the President of Ukraine

Address: 20, Ezhena Pottier Str., Kyiv, 03057, Ukraine

E-mail: general@academy.gov.ua 